\title{
Human ontogenesis: An indigenous African view on development and intelligence
}

\author{
A. Bame Nsamenang \\ Ecole Normale Superieure du Cameroun, Bambili Campus, Cameroun
}

\begin{abstract}
$V$ iews on development and intelligence mirror mainstream Euro-American ethnocentrism and are presented as being applicable to all of human diversity. In contrast, an African worldview visualizes phases of human cyclical ontogenesis of systematic socialization of responsible intelligence in participatory curricula that assign stage-appropriate developmental tasks. In these curricula, knowledge is not separated into discrete disciplines, but all strands of it are interwoven into a common tapestry, which is learned by children at different developmental stages, who participate in the cultural and economic life of the family and society. This line of thought permits the integration of diverse ethnocultural realities and disparate theoretical threads into a common conceptual system - social ontogenesis. A theory of social ontogenesis addresses how, throughout ontogeny, children are co-participants in social and cultural life. The theory anchors human development as partly determined by the social ecology in which the development occurs and by how the human being learns and develops. Its seminal concept is sociogenesis, defined as individual development that is perceived and explained as a function of social, not biological, factors. But social ontogenetic thinking does not exclude nature; it assumes that biology underpins social ontogenesis. The biological commonality that the human species shares in the genetic code plays out into a bewildering diversity of specific individuality across ecocultures. Thus, contextualist theorists stress how different ontogenetic pathways and intelligences are situated in the socio-ecological contexts and cultural systems in which children are nurtured. The empirical grounding of this theory is based on impressionistic data from the Nso people of Cameroon, with supportive evidence in other parts of Africa. The universality of social ontogenesis offers an innovative impetus to conceptualize and generate developmental knowledge that empowers. It is a learning paradigm that permits the study of human development in the context of children's engagement of cognition when they are participants in cultural communities. This can expand visions and databases beyond restrictive Eurocentric grids.
\end{abstract}

es points de vue sur le développement et l'intelligence reflètent l'ethnocentrisme euro-américain dominant et
sont présentés comme étant applicables à toute la diversité humaine. En contrepartie, une vision du monde
africaine se représente les phases de l'ontogenèse humaine cyclique de la socialisation systématique de
l'intelligence responsable dans les programmes participatifs qui assignent des tâches appropriées aux stages de
développement. Dans ces programmes, la connaissance n'est pas séparée en disciplines distinctes, mais tous ses
enchaînements sont entrelacés dans une tapisserie commune. Cette dernière est apprise à des stages de
développement différents par les enfants qui participent à la vie culturelle et économique de la famille et de la
société. Cette ligne de pensée permet d'intégrer diverses réalités ethnoculturelles et des discours théoriques
disparates dans un système conceptuel commun-l'ontogenèse sociale. Une théorie de l'ontogenèse sociale
aborde la façon dont, à travers l'ontogénie, les enfants collaborent à la vie sociale et culturelle. La théorie
s'enracine dans le développement humain comme étant partiellement déterminé par l'écologie sociale dans
laquelle il apparaît et dans la façon dont l'être humain apprend et se développe. Son concept séminal fait
référence à la sociogenèse, laquelle est définie comme le développement individuel qui est perçu et expliqué en
fonction de facteurs sociaux et non biologiques. Mais la pensée ontogénétique sociale n'exclut pas la nature; elle
suppose que la biologie sous-tend l'ontogenèse sociale. Les aspects biologiques communs partagés par l'espèce
humaine dans le code génétique se manifestent dans une diversité déconcertante de l'individualité spécifique d'une
culture à l'autre. Ainsi, les théoriciens contextualistes insistent sur la façon dont les trajectoires ontogénétiques
différentes et les intelligences sont situées dans les contextes et les systèmes culturels dans lesquels les enfants sont
éduqués. La base empirique de cette théorie est appuyée sur des données impressionnantes du peuple Nso du
Cameroun, avec des appuis en provenance des autres parties d'Afrique. L'universalité de l'ontogenèse sociale

Correspondence should be addressed to Dr A. Bame Nsamenang, Ecole Normale Superieure, Bambili Campus, C/O P.O. Box 270, Bamenda, Cameroon.

(C) 2006 International Union of Psychological Science

http://www.psypress.com/ijp

DOI: $10.1080 / 00207590544000077$ 
offre un élan innovateur pour conceptualiser et générer une connaissance du développement qui prend de la puissance. Il s'agit d'un paradigme d'apprentissage qui permet l'étude du développement humain dans le contexte dans lequel les enfants s'engagent à la cognition en tant que participants dans les communautés culturelles. Ceci peut étendre les visions et les bases de données au-delà des grilles restrictives eurocentriques.

\begin{abstract}
T as perspectivas del desarrollo y de la inteligencia reflejan el etnocentrismo euro-estadounidense actual y $\mathcal{L}$ resultan aplicables a toda la diversidad humana. En contraste, una visión del mundo africana visualiza fases de la ontogenia humana cíclica de la socialización sistemática de la inteligencia responsable en currícula participativos que asignan tareas apropiadas a los estadíos del desarrollo. En estos currícula el conocimiento no se separa en disciplinas discretas, sino que todas sus hebras se encuentran entretejidas en una misma tela, que los niños aprenden en las distintas etapas de su desarrollo, a la vez que participan en la vida cultural y económica de la familia y la sociedad. Esta línea de pensamiento permite la integración de diversas realidades etnoculturales e hilos teóricos dispares en un sistema conceptual común-la ontogenia social. Una teoría de la ontogenia social aborda como, a lo largo de la ontogenia, los niños coparticipan en la vida cultural y social. La teoría ancla al desarrollo humano como parcialmente determinado por la ecología social en la cual el desarrollo ocurre y como la persona aprende y se desarrolla. Su concepto seminal es la sociogénesis, definida como el desarrollo individual percibido y explicado como una función de factores sociales, y no biológicos. Pero el pensamiento de ontogenia social no excluye a la naturaleza; supone que la biología subyace a la ontogenia social. Los aspectos biológicos comunes que la especie humana comparte en el código genético se manifiesta en una diversidad desconcertante de individualidad específica de una cultura a otra. Por lo tanto, las teorías contextualistas subrayan cómo diversos senderos ontogénicos e inteligencias se sitúan en los contextos socio-ecológicos y en los sistemas sociales en los que los niños se crían. El fundamento empírico de esta teoría se basa en datos impresionistas del pueblo Nso de Camerún, con datos que apoyan de otras partes de África. La universalidad de la ontogenia social ofrece un ímpetu innovador para conceptuar y generar el conocimiento del desarrollo que proporciona poder. Es un paradigma de aprendizaje el que permite el estudio del desarrollo humano en el contexto en el que los niños se usan la cognición como participantes en comunidades culturales. Esto puede expander las visiones y las bases de datos más allá de los enrejados restrictivos eurocéntricos.
\end{abstract}

\section{INTRODUCTION}

Indigenous psychologies connote indigenous roots. This notion involves a consideration of the process of immigration-emigration and human settlement in parts of the globe that are remote from ancestral or indigenous lands. Work on migration and settlement, however, suffers from bias, as it tends to be applied in reference to European emigration and settlement in other people's indigenous lands. Outside Europe and the US, the minority-majority status is not accorded a prominent place in social policy when it concerns the emigration and settlement of nonEuropean peoples. Thus, the push to adopt the Eurocentric knowledge of mainstream psychology as "universal knowledge" has relegated knowledge of worldwide human development to a homogeneous, minority status. The heterogeneous and diverse knowledge about "the $85 \%$ plus of the world that is not part of Europe and North America" (Knutsson, cited in Pence, 1999, p. 15), has been marginalized as "indigenous psychologies."

This article presents a perspective on human development and intelligence that is indigenous to Africa south of the Sahara. Its framing principle is an African precept of not shredding human knowledge into discrete disciplines. In indigenous African education, all strands of knowledge are interwoven into a common tapestry (Moumouni, 1968), which is learned in a participatory curriculum. This line of thought permits the integration of diverse ethnocultural realities and disparate theoretical threads into a common conceptual system, that of social ontogenesis (Nsamenang, in press-b).

A theory of social ontogenesis addresses how, throughout ontogeny, humans engage social cognition as participants in cultural communities (Rogoff, 2003). Empirical support has been gleaned from impressionistic research with the Nso people of Cameroon (see Nsamenang, 1992, 2001, 2004; Nsamenang \& Lamb, 1994, 1995) and substantiated by research in other parts of Africa (e.g., Asante, 1990; Babatunde, 1992; Beattie, 1980; Jahoda, 1982; Rogoff, 2003; Serpell, 1993; Zimba, 2002).

\section{THEORETICAL MOORINGS AND CONCEPTUAL ISSUES}

Social ontogenesis anchors human development partly within the ecology and social system in which the development occurs (Ngaujah, 2003). Stated differently, ecocultural factors are implicated in how the human person learns and 
develops (see Berry, 1994). In fact, contextualist psychologists have stressed how different ontogenetic pathways and intelligences are situated in the ecological and social systems in which children are nurtured. Thus, social ontogenesis is rooted in the traditions of ecological and cultural theorizing.

The seminal concept of social ontogeny is "sociogenesis," defined as individual development perceived and explained as a function of social, not biological, factors. Social ontogenetic thinking, thus, does not exclude nature, but assumes that biology undergirds social ontogenesis. In fact, the biological commonality the human species shares in the genetic code plays out into a bewildering diversity of specific individuality (Maquet, 1972) groomed in different ecocultural contexts. An Africentric view on development, therefore, focuses on nurture, to posit a theory of human development that gives much attention to the milieu in which development occurs (Ngaujah, 2003).

The plasticity of the biological timetable allows every culture to imprint its text onto processes of biological ontogenesis. It permits the transformation of a biotic system, the human being, into a cultural agent. Accordingly, it sounds plausible not to expect universally applicable milestones of human development, since every culture recognizes and assigns different developmental tasks to their perceived phases of human ontogenesis.

\section{HUMAN ONTOGENESIS}

Developmental science sometimes invokes notions of the human lifespan and life cycle, but does not articulate them. An African worldview envisions the human life cycle in three phases of selfhood (Nsamenang, 1992). There is a spiritual selfhood, which begins at conception, or perhaps earlier in an ancestral spirit that reincarnates. It ends with the ceremony to confer a name on a newborn. A social or experiential selfhood continues the cycle from the rite of incorporation or introduction of the child into the human community through naming, to end with biological death. Death is more acceptable in old age. An ancestral selfhood follows biological death.

In general, ancestors are the living dead (Mbiti, 1990), or spiritual presences in the affairs of the living. Some ancestors stand out as the loving dead. A cursory examination of the intentions and meanings of funeral rites and the memories people hold of loved ones for decades, even centuries, after their death can identify this class of ancestors to substantiate the universality of a selfhood that transcends the existential self. Some cultures claim the rebirth or reincarnation of their loving dead to complete the unbroken circle of being human (Zimba, 2002).

\section{Social ontogenetic stages and developmental tasks}

Social selfhood, the experiential phase of personhood, develops through seven stages. These include a period of the newborn, social priming, social apprenticing, social entrée, social internment, adulthood, and old age and death (see Nsamenang, 1992, pp.144-148). Adding the two metaphysical phases of human selfhood to the seven stages of social ontogenesis completes the human life cycle.

Each stage of ontogenetic development is marked by distinctive developmental tasks, defined within the framework of cultural realities and developmental agenda (Nsamenang, 2000; Nsamenang \& Lamb, 1995). We interpret development in African social thought "as the acquisition and growth of the physical, cognitive, social, and emotional competencies required to engage fully in family and society" (Nsamenang, 2005). For Rogoff (2003), this type of development is transformation in the individual brought about by participation in cultural activities. Such mentality primes Africans to guide child development as a process of gradual and systematic social integration. This conceptualization of human ontogenesis "differs in theoretical focus from the more individualistic accounts proposed by Freud, Erikson and Piaget" (Serpell, 1994, p. 18).

As children are initiated into and actively engage in cultural life, they gradually and systematically individuate into and assume particular levels of personhood, identity, and being. Individuation is the process by which the human being comes to a sense of self and personal identity in search of individuality - an imprint on the human person by the ecoculture. Within the African worldview, human beings not only need other humans but also social responsibility to individuate adequately and attain full personhood. Thus, a sense of self cannot be achieved without reference to the community of other humans in terms of being interconnected and enacting one's social roles. The social ontogenetic paradigm is premised not on an independent or autonomous frame; its foundational principle is an interdependent or relational script. It would be enriching to scrutinize the relational script as a challenge to, or alternative or complement to, the individualistic ideology of mainstream developmental psychology. 
African parents expect children to assume social responsibility from an early age as a primary value over and above social cognition as an endstate (Nsamenang, 2005). As children grow, they are progressively assigned different roles on perception of their social maturity or competence. For African parents, social cognition translates into responsible intelligence, not in abstraction, but primarily as it enhances the attainment of social ends (Nsamenang, 2003b). The "concern with responsible ways of contributing to the social world" (Greenfield, Keller, Fulgni, \& Maynard, 2003, p. 464) highlights responsible or social intelligence (Mundy-Castle, 1974; Nsamenang, 2003a). This value orientation infuses the socialization of responsibility into African parenting attitudes and programmes. In consequence, in African family traditions, "Socialization is not organized to train children for academic pursuits or to become individuals outside the ancestral culture. Rather, it is organized to teach social competence and shared responsibility within the family system and the ethnic community" (Nsamenang \& Lamb, 1994, p. 137).

\section{INDIGENOUS VIEWS ON COGNITION AND INTELLIGENCE}

Indigenous developmental psychology can promote understanding of social cognition-how a given people learn and use knowledge. Jahoda and Lewis (1988) alerted the field to this possibility when they recommended moving "beyond the relatively narrow confines of cognitive development in crosscultural studies" to "advance our understanding of the manner in which children come to adopt the prevailing social categories, values and norms in the context of their widening social relationships" (p. 29). The value of knowing not only how children grow up thinking, but also feeling and acting, in a given society cannot be overemphasized. As it targets developmental phenomena in context, social ontogeny permits understanding of theory in close proximity to actual psychological phenomena (Valsiner, 1997), hence its potential value in interventions.

\section{The cultural content of intelligent behaviour}

How children are taught or teach themselves to become competent members of their communities varies across cultures. In some societies children learn in schools; in others, they learn from active involvement in the life of families and communities. As African cultures recognize different phases of children's emerging minds, they tacitly wed their participatory curricula to sequences of perceived cognitive capacities (Nsamenang, 2003b).

The embedded knowledge, skills, and values children learn from these curricula are not compartmentalized into this or that activity, knowledge, or skill domain, but are massed together as integral to social interaction, cultural life, economic activities, and daily routines (Nsamenang, in 2005). In principle, children are rarely instructed or prodded into what they learn, but discover it during participation. This depicts cognitive development as the unfolding of the abilities to generate the knowledge and skills with which to responsibly and increasingly engage with the world. Accordingly, the onus to understand the social cognition and intelligent behaviour of Africans lies in capturing shared routines and participatory learning, rather than in completing school-based instruments.

An evaluative criterion with which African parents determine intelligent behaviour is social responsibility (Mundy-Castle, 1974). To train responsibility, parents and caregivers allocate chores to children or send them on neighbourhood errands (Ogunaike \& Houser, 2002). The "work" children do socializes cognition, values, and productive skills. It also generates knowledge and eases social integration. Some parents use evidence that a child has ability to give and receive social support, and notice and attend to the needs of others, as markers of mental and general developmental level (Weisner, 1987). In Zambia, for instance, adults "keep some mental tally of the proportion of errands that a given child performs adequately, and this serves as an index of how 'tumikila' the child is. In the short term, this attribute is used to choose which child to send on another such errand" (Serpell, 1993, p. 64). Episodes of a child's accurate enactment of roles feed into a history of that child's social competence; indeed, of their responsible intelligence.

In traditional Africa, the peer group plays a pivotal role in the development of this genre of cognition because, from toddlerhood, the child comes more under the purview of the peer culture than of the adult world.

\section{CONCLUDING STATEMENT}

It is unclear if developmental psychology that is ordained for universal applicability has matured beyond excluding " $95 \%$ of the world's children" (Zukow, 1989, p.2)! The Eurocentrism of the discipline pulls Africans "away from their roots, away from their own knowledge, and away 
from their own knowledge holders, into a chasm of dependency on others whose values and understandings have been shaped in very different cultures, histories and environments" (Knutsson, cited in Pence, 1999). Indigenous psychologies stand to enrich the discipline if developmental researchers could perceive their role first and always as a learner (Ngaujah, 2003). Accordingly, we have proposed a theory of social ontogeny as a learning posture (Agar, 1986) "to stir up interest and systematic exploration of distinctly indigenous patterns of development so that developmental research in Third World contexts may fertilize and expand the visions, methods, and knowledge of psychology beyond current (Western) moulds" (Nsamenang, 1992, p. 4).

\section{REFERENCES}

Agar, M. H. (1986). Speaking of ethnography. Newbury Park, CA: Sage.

Asante, M. K. (1990). Kemet, Afrocentricity and knowledge. Trenton, NJ: Africa World Press.

Babatunde, E. D. (1992). A critical study of Bini and Yoruba value systems of Nigeria in change: Culture, religion and self. Lewiston, NY: The Edwin Mellen Press.

Beattie, R. F. (1980). Representations of the self in traditional Africa. Africa, 50, 313-520.

Berry, J. W. (1994). An ecocultural perspective on human development. In E. Trickett (Ed.), Human diversity. San Francisco: Freeman.

Greenfield, P. M., Keller, H., Fulgni, A., \& Maynard, A. (2003). Cultural pathways through universal development. Annual Review of Psychology, 54, 461-490.

Jahoda, G. (1982). Psychology and anthropology. London: Academic Press.

Jahoda, G., \& Lewis, I. M. (1988). Child development in psychology and anthropology. In G. Jahoda \& I. M. Lewis (Eds.), Acquiring culture: Cross-cultural studies in child development (pp.1-34). London: Routledge.

Maquet, J. (1972). Africanity. New York: Oxford University Press.

Mbiti, J. S. (1990). African religions and philosophy. Oxford: Heinemann Educational.

Moumouni, A. (1968). Education in Africa. New York: Praeger.

Mundy-Castle, A. C. (1974). Social and technological intelligence in Western and non-Western cultures. Universitas, 4, 46-52.

Ngaujah, D. E. (Fall, 2003). An eco-cultural and social paradigm for understanding human development: $A$ (West African) context. Graduate Seminar Paper (supervised by Dr Dennis H. Dirks), Biola University, CA.

Nsamenang, A. B. (1992). Human development in cultural context: A Third World perspective. Newbury Park, CA: Sage.

Nsamenang, A. B. (2000). Issues in indigenous approaches to developmental research. ISSBD Newsletter, 1, 1-4.
Nsamenang, A. B. (2001). Indigenous view on human development: A West African perspective. In N. J. Smelser \& P. B. Baltes (Eds-in-Chief). International Encyclopedia of the Social and Behavioral Sciences (pp. 7297-7299). London: Elsevier.

Nsamenang, A. B. (2003a). Conceptualizing human development and education in sub-Saharan Africa at the interface of indigenous and exogenous influences. In T. S. Saraswathi (Ed.), Cross-cultural perspectives in human development: Theory, research, and applications (pp. 213-235). New Delhi: Sage.

Nsamenang, A. B. (2003b, February). An African ontogeny of social selfhood: Social cognition or responsible intelligence? Paper presented at the 2002/2003 Fellows Seminar Series, Center for Advanced Study in the Behavioral Sciences, Stanford University.

Nsamenang, A. B. (2004). Cultures of human development and education: Challenge to growing up African. New York: Nova.

Nsamenang, A. B. (2005). The intersection of traditional African education with school learning. In L. Swartz, C. de la Rey \& N. Duncan (Eds.), Psychology. Oxford: Oxford University Press.

Nsamenang, A. B., \& Lamb, M. E. (1994). Socialization of Nso children in the Bamenda grassfields of northwest Cameroon. In P. M. Greenfield \& R. R. Cocking (Eds.), Cross-cultural roots of minority child development (pp.133-146). Hillsdale, NJ: Lawrence Erlbaum Associates Inc.

Nsamenang, A. B., \& Lamb, M. E. (1995). The force of beliefs: How the parental values of the Nso of Northwest Cameroon shape children's progress towards adult models. Journal of Applied Developmental Psychology, 16, 613-627.

Ogunaike, O. A., \& Houser, R. F. Jr (2002). Yoruba toddler's engagement in errands and cognitive performance on the Yoruba Mental Subscale. International Journal of Behavioral Development, 26, $145-153$.

Pence, A. R. (1999, April). ECCD: Through the looking glass. A keynote address presented at the ECCD World Forum, Honolulu, Hawaii.

Rogoff, B. (2003). The cultural nature of human development. New York: Oxford University Press.

Serpell, R. (1993). The significance of schooling. New York: Cambridge University Press.

Serpell, R. (1994). An African social selfhood: Review of A. Bame Nsamenang (1992): Human development in cultural context. Cross-Cultural Psychology Bulletin, $28,17-21$

Valsiner, J. (1997). Culture and development of children's action: A theory of human development. New York: Wiley.

Weisner, T. S. (1987). Socialization for parenthood in sibling caretaking societies. In J. B. Lancaster, J. Altman, A. S. Rossi, \& L. R. Sherrod (Eds.), Parenting across the lifespan: Biosocial dimensions (pp. 237-270). Hawthorne, NY: Aldine de Gruyter.

Zimba, R. F. (2002). Indigenous conceptions of childhood development and social realities in southern Africa. In H. Keller, Y. P. Poortinga, \& A. Scholmerish (Eds.), Between cultures and biology: Perspectives on ontogenetic development (pp.89115). Cambridge: Cambridge University Press.

Zukow, P. G. (1989). Sibling interactions across cultures: Theoretical and methodological issues. New York: Springer-Verlag. 